\author{
Ж.Д. Дәдебаев \\ Әл-Фараби атындағы Қазақ ұлттық университеті, Қазақстан, Алматы қ. \\ e-mail: dadebaev48@gmail.com

\section{АБАЙ ІАІМІН БІАУ, TYCIHУ ЖӘНЕ KОАААНУ}

\begin{abstract}
Мақалада Абай ілімінің басты категориялары, олардың мазмұны, өзара байланыстары жүйеленді. Абайдың шығармашылық мұрасын зерттеу жұмыстары түрлі бағытта, түрлі ғылым салаларында жүргізілді және жүргізіліп келеді. Абайдың өмірі мен шығармашылығын тану мен танытуға арналған көптеген монографиялар, оқулықтар мен оқу құралдары, мақалалар жинағы, конференция материалдары жарық көрді. Шетелдерде бірқатар еңбектер жарияланды. Соған қарамастан Абайдың шығармашылық мұрасын зерттеу саласында шешімін күтіп жатқан өзекті, әлеуметтік маңызы зор ғылыми мәселелердің бірі Абай ілімі. Абайтану саласында бүгінгі күнге дейін жасалған жұмыстарда көптеген ірі мәселелер шешілді, зерттеу жұмыстары жалғастырылуда. Бірақ Абай мұрасын Абай ілімінің құрылымдық жүйесі мен пәнаралық өрістерін анықтау мақсатында арнайы зерттеу жұмыстары жүргізілмеген-ді. А^ Абайдың ілімінің пәнаралық өрістері мен бірбүтін құрылымдық жүйесін анықтау, сөйтіп Абай ілімін білу, түсіну және қолдану әлеуметтік, қоғамдық-гуманитарлық, ғылым саласында маңызды жетістік болатыны анық. Күтілетін ғылыми нәтижеге жету жолындағы зерттеу жұмыстары Абай ілімін зерттеу мен эстетикалық қабылдаудың методологиялық ұстанымдары түсіну (герменевтика), пайымдау (интерпретация), бағалау (оценка) аясында негізделді. Абай ілімінің өлшеу құралы сарапталып, оның құрылымы анықталып, ғылыми сипаттамасы жүйеленді.
\end{abstract}

Түйін сөздер: Абай ілімі, концепт, түсіну, пайымдау, бағалау, білім, сенім.

$$
\begin{gathered}
\text { Zh.D. Dadebayev } \\
\text { Al-Farabi Kazakh National University, Kazakhstan, Almaty } \\
\text { e-mail: dadebaev48@gmail.com }
\end{gathered}
$$

\title{
Knowledge, comprehension and application of Abai studies
}

The article systematizes the main categories of Abai studies, their content and relationship. Abai's creative heritage was studies and continues to be studies in different directions, in different fields of science. Many monographs, textbooks and teaching aids, collections of articles, materials of conferences dedicated to the life and work of Abai have been published. A number of works have been published abroad. Nevertheless, one of the most urgent and socially significant scientific issues in the study of Abai's creative heritage is Abai studies. To date, many serious issues in the field of Abai studies have found their solution, research is still going on. However, no special studies have been carried out to determine the structural system and interdisciplinary areas of the Abai heritage and teachings of Abai. It is obvious that the identification of interdisciplinary areas and a unified structural system of Abai studies, which means that knowledge, comprehension and application of Abai's teachings will be an important achievement in the field of social and humanitarian sciences. The research work to achieve the expected scientific result was based on the methodological principles of studying and aesthetic perception of Abai studies in hermeneutics, interpretation, and evaluation. The measuring instrument of Abai studies is analyzed, its structure is determined and its scientific characteristics are systematized.

Key words: Abai studies, concept, comprehension, interpretation, evaluation, knowledge, trust.

$$
\begin{gathered}
\text { Ж.А. АаАебаев } \\
\text { Казахский национальный университет имени аль-Фараби, Казахстан, г. Алматы } \\
\text { e-mail: dadebaev48@gmail.com } \\
\text { Знание, понимание и применение учения Абая }
\end{gathered}
$$

\section{Знание, понимание и применение учения Абая}

В статье систематизированы основные категории учения Абая, их содержание и взаимосвязь. Творческое наследие Абая изучалось и продолжает изучаться в разных направлениях, в разных областях науки. ИзАано много монографий, учебников и учебных пособий, сборников статей, материалов конференций, посвященных жизни и творчеству Абая. Ряд работ опубликован за рубежом. Тем не менее, одним из наиболее актуальных и социально значимых научных 
вопросов в области изучения творческого наследия Абая является учение Абая. На сегодняшний Аень многие серьезные вопросы в области абаеведения нашли свое решение, исследования продолжаются. ОАнако никаких специальных исследований для определения структурной системы и междисциплинарных областей наследия Абая и учения Абая не проводилось. Очевидно, что выявление междисциплинарных областей и единой структурной системы учения Абая, а значит и знание, понимание и применение учения Абая станут важным Аостижением в области социальных и гуманитарных наук. Исследовательская работа Аля достижения ожидаемого научного результата строилась на методологических принципах изучения и эстетического восприятия учения Абая - герменевтике, интерпретации, оценке. Проанализирован измеритель учения Абая, определена его структура и систематизированы его научные характеристики.

Кмючевые слова: учения Абая, концепт, понимание, интерпретация, оценка, знание, доверие.

\section{Kipicпe}

Еліміз тәуелсіздік алғаннан бергі абайтануда жаңа заманауи ғылым жетістіктері негізінде жүргізілген пәнаралық зерттеулер болды. «Абайдың шығысы», «Абайдың толық адам ілімі», «Абайдың кітапханасы», т.б. тақырыптар өзіндік тың деректермен толықты.

Абай ілімін білу, түсіну және қолдануды бар нәрсенің құрылым-жүйесін жобалау деп түсінуге болмайды. Бұл - көп құрамды, көп салалы, көп деңгейлі, күрделі және бірбүтін жүйені танудың жолы, зерттеудің әдісі. Әдіс негізінде концептуалды қағидалар мен концептілердің құрамы, үлгілері сипатталды. Концептілер мен күрделі, көп құрамды құбылыстарды анықтаудың амалдары пайымдалды. Күрделі, көп құрамды құбылыстар моделінің түрлері көп. Бірбүтін құбылысты зерттеу оны құрамдас бөліктерге бөлу, ол бөліктердің өзара қарым-қатынасын саралау, мәнін анықтау арқылы жүзеге асады. Бірақ Абайдың ілімін тануды оны бүтін мен бөлшек шегінде қарастыру деп түсіну жеткіліксіз. Зерттеліп отырған құбылыс жүйесінде бүтінге де, бүтіннің бөлшегіне де жатпайтын, бірақ олармен шектес басқа құбылыстар да болады. Оларды анықтау, олардың мәнісін білудің маңызы зор. Осы тұрғыдан келгенде, Абай ілімінің концептуалды үлгі-моделі - болмыстағы шындық құбылыстарды бейнелеудің Абайға тән үлгісі. Абай ілімін білу, түсіну және қолдану - Абайды танудың айрықша құралы.

Абай шығармашылығында көрініс тапқан ұлттық мәні бар қағидаларды, әдеп өлшемдерін, жалпыадамзаттық таным таразысында саралау Абай ілімін білумен байланысты анықталады. Абай ілімінде адамның адамшылығының негізінде, оның қалыптасуы мен дамуында, өркендеуінде білімнің алатын орнына үлкен мән беріледі. Білім - Абайдың шығармашылық мұрасындағы басты құндылық және барша құндылықтардың негізі.
Абайдың ілімінің мағыналық-құрылымдық жүйесін түзетін басты ұғымдар мен түсініктер, олардың әрқайсысының өзіне тән ерекшеліктері, сыртқы қырлары мен ішкі сырлары, өзара байланысы, қарым-қатынасы, олардың өніп-өсуі мен өзара қауымдасу, тұтасу жолдары жан-жақты сараланды.

Зерттеу нысанын бірбүтін құбылыс ретінде қабылдап, оны құрамдас бөліктерге бөліп саралау, әр құрамдас бөліктің қасиеттерін, басқа бөліктермен қатынасын анықтау бағытында ізденіс жұмыстары жүргізілді, жаңа тұжырымдар жасалды. Абай ілімінің құрамдас бөлімдерінің әрқайсысы күрделі, көп құрамды, олардың құрамдас бөліктерінің арасындағы байланыстардың қызметі ерекше. Абай ілімінің құрамдас бөлімдері өзара ғана емес, өздерімен шектес, шендес басқа құбылыстармен де сабақтасады. Мұндай көп құрамды, көп тарамды, күрделі қатынастағы құбылысты бірбүтін қалыптау бағытында көп қырлы ізденіс жұмыстары жүргізілді.

\section{Зерттеу материалы және әдістері}

Абай ілімін білу, түсіну және қолдану оның шығармаларының өзегіндегі құндылықтар арқылы анықталады. Ол құндылықтардың мағынасы тірек сөздер жүйесі арқылы ашылады. Солардың қатарында білім және сенім концептілері беретін концептуалды мағыналар жүйесінің маңызы зор. Олар Абайдың ілімінің өзекті желісін түзеді. Сондықтан бұл концептілердің әрқайсысы көпдеңгейлі, көпқырлы ұғымдардың өзегі, негізі ретінде бірбүтін күрделі құбылыс аясында түрлі қызмет атқарады. Солардың қатарында мынадай қызметтерін ерекше бөліп атауға болады: танымдық қызметі; көркемдік-эстетикалық қызметі; жаңа мағыналық-құрылымдық бірлік түзу қызметі.

Аталған қызметтеріне қарай білім және сенім концептілерінің сипаттары да түрліше болады: 
образды сипаты; нақты сипаты; өзімен шендес, шектес құбылыстармен астасуымен байланысты пайда болатын сипаты. Әр концептінің құрылым-жүйесін анықтауда оның осындай ерекшеліктерін ескеруге тура келеді.

Концепт ұғымы тіл біліміне философиядан келген, латынша концептус (ұғым) сөзінің калькасы болып табылады. Бірақ «концепт», «ұғым» терминдерінің негізі бір болғанмен, мәні, маңызы бірдей емес. Ұғым - объектінің танылған маңызды белгілерінің жиынтық бейнесі болса, концепт - этностық ерекшеліктермен байланысты менталдық құрылым, ол - мазмұны жағынан белгілі объект жайындағы білімнің жиынтығы, ал көріну формасы (білдірілуі) жағынан барлық тілдік құралдардың (лексикалық, фразеологиялық, паремиологиялық т.б.) жиынтығы.

Когнитивтік лингвистика мен лингвомәдениеттану ғылымдарының негізгі зерттеу категориясы концепт болып келетініне қарамастан, оны ұғыну мен түсіну тәсілдері бірдей емес.

Лингвомәдениеттанудағы концепт - мәдениеттің базалық бірлігі. «Сенім» мен «білім» концептілеріне де қатысты. Оның өзіндік өрісі, моделі бар. Бұл концептілер - тілді, сана мен мәдениетті комплексті зерттеу жүйесіндегі шартты ментальді бірлік. Лингвомәдени концепт басқа ментальді бірліктерден белгілі бір мәніне байланысты маңызды бірлікті даралау арқылы ерекшеленеді. «Сенім», «білім»- лингвомәдени концептілер. Олар-жекенемесе қоғамдық санада болатын, жоғарыда айтылып кеткендей, белгілі бір мәніне байланысты дараланған бірліктен басқа ұғымдық (концепттің тілдік фиксациясы, оның белгісі, сипаты, дефинициясы) және бейнелік (біздің есімізде бейнеленген заттардың, құбылыстардың, оқиғалардың моделін, сипаттамаларын қабылдау) элементтердің тұтастығымен сипатталатын үш компонентті құрылым.

\section{Әдебиеттерге шолу}

Абай ілімін білу, түсіну және қолдану ақынның шығармашылық мұрасын, өмірбаянын жан-жақты зерттеу нәтижелеріне сүйену арқылы жүзеге асады. Бұл абайтану тарихындағы алғашқы еңбектерден бастап бүгінгі іргелі зерттеулерді қамтиды. Абайдың ғылыми өмірбаянын жасау жолындағы М. Әуезовтің еңбегінің маңызы мен мәні зор. Оның тереңіне бойлау оңай емес. Сол оңай емес, қиын мәселе М. Мырзахметовтің монографиялық зерттеуінде алғаш рет арнайы қарастырылып, нақты шешімін тапты. Бұл орайда М. Мырзахметов М. Әуезовтің еңбегін мынадай салалар бойынша пайымдайды: Абайдың өмірбаяны және ондағы тарихи деректер көзі; Абай өмірбаянының соны деректермен қорлануы; Абай өмірбаянының төрт нұсқасы; өмірбаяндық деректерді екшеу тәсілдері (Мырзахметов, 2017). Осы салалардың әрқайсысы бойынша зерттеуші мол дерек көздерін табады, Абайдың ғылыми өмірбаянын жасау, жетілдіру, толықтыру бағытында М. Әуезов қол жеткізген жетістіктерді нақты талдаулар негізінде терең пайымдап, әділ бағалайды.

Абайтану ғылымының негізін қалау, оны ғылым және оқу пәні ретінде қалыптастыру әлФараби атындағы Қазақ ұлттық университетінде басталып, жүзеге асқан болатын. М.О. Әуезов осы университетте ұстаздық ете жүріп, абайтану саласында мынадай іргелі істерді бітірді: Абайдың ғылыми өмірбаянын жасады; Абай туралы монографиялық зерттеуін жазды (Әуезов, 1985); Абай, Абайдың заманы туралы «Абай жолы» роман-эпопеясын дүниеге әкелді; «Абайтану» ғылымын қалыптастырды.

М.О. Әуезовтың «Абай жолы» роман эпопеясы әлем тілдеріне аударылып, қазақ қоғамының, дәстүрінің насихатына айналды. Эпопеядағы Абай образы жастайынан зеректікті, есейгендегі кемелдікті көрсететін туынды (McGuire, 2020: URL). «Абай жолы» роман-эпопеясының шетел тілдеріне аударылуы халқымыздың тарихын, мәдениетін, рухани байлығын әлемге танытады. Бұл шетел тілдеріне эпопеяның еш қиындықсыз аударыла салады деген сөз емес. Ұлттың дәстүріне, сөздік қорының молдығына, бір тілден екінші тілге аударылғандағы кей сөздердің баламалы атауларының табылмауы көптеген кедергі келтіретіні сөзсіз. Аударма жасалатын тілдегі фразеологизмдердің аударылуы туралы зерттеу жұмысында да ғалымдар «Абай жолы» роман-эпопеясын негізге алады (Тарақов, 2015: 372).

Аударма мәдениетаралық қарым-қатынастың негізі. Абай ілімін білу және түсіну үшін қазақ тілін жақсы меңгерген, ақынның айтпақ болған ойын дұрыс ұға білетін аудармашының жасаған аудармасы болғаны жақсы. Абай ілімін жүйелеу, ұсыну барысында әлемдегі ақын шығармаларының рецепциясын да жетік білген жөн. Бұл шет елдердің Абай дүниетанымын дұрыс түсініп, еліміздің рухани мұрасын тануының кепілі болмақ (Жапарова, 2016: 311).

Абайдың саяси және әлеуметтік лирикасының адам баласының адамшылығын қозғалыс үстінде сипаттауы көрінеді. Абайдың қоғамдағы келеңсіз жайттарды өткір сынауы өмір шынды- 
ғынан алынғандықтан әлі де маңызға ие тақырыптар қатарында екеніне көз жеткіземіз (Дәуренбекова, 2020: 1857).

Абай ілімін білу, түсіну және қолдану аясының кеңеюі еліміз үшін де маңызды рухани шара. Абай сөздерінің халық арасында маңызға ие екендігі және түрлі жағдайда жатқа дәйек сөз ретінде қолданылуы, нақылға айналуы ақынның шын хакім екенін көрсетсе керек. Сондықтан да «Қазақ ақыны және философы Абай - қазақстандық мәдениет пен қоғамдағы канондық тұлға» (Кұдайбергенова, 2020: URL) деген пікірдің орынды екенін аңғарамыз.

Абай өз заманында халықтың оқығанын, білім алғанын, дамыған, өркениетті елдер қатарында, солармен тең боларлық ел болуды, халықтың сана-сезімінің өсуін, толысуын аңсайды. Абай ілімінің негізінде білімге шақыру жатқанын аңғаруға болады. «Сөзі үлкен салмаққа ие болған Абай қазақтарға балаларын мектепке жіберуге шақырады. Дала оның шақыруына жауап береді» (Әуезов, 2020: URL). Абай арманы, Абай көздеген мақсат алыс болашақты ойлаудан туған, қай кезде де маңызын жоймайтын құндылықтар еді. Мұны Қ. Байзақова өзінің «Әл-Фараби және Абай» атты мақаласында: «Абай ұмтылған мұраттар ұлттық шеңбермен ғана шектелмейді - олардың жалпыадамзаттық үндеуі бар» (Байзақова, 2020: URL) деп атап өтеді.

Абай өлеңдеріндегі метафораларды зерттеген Ә. Жапарова ақын шығармаларындағы метафоралардың функционалды құрылымын (Жапарова, 2016а: 42-52), концептуалды метафораларды (Жапарова, 2016b: 54-59) талдай отырып Абай ілімін білу, түсіну және қолдану аясының кеңдігіне көз жеткізеді. Абай шығармаларындағы метафоралар ақынның табиғатты тануы, адамның ішкі және сыртқы сырларын ұғуы жайынан мол дерек береді.

Ғалым М. Мырзахметұлы Абай шығармаларындағы «Толық адам» идеясын ілім деңгейінде тану, ғылыми жүйелеу мен насихаттау бағытында еңбектеніп келеді. Ғалымның «Абайдағы мораль философиясына байланысты гуманистік ойдың өзекті бір желісі - көбінесе, толық адам, жарым адам, толық инсаният, пенделіктің кәмаләттығы, кәмаләт ғазамат деген өз заманы мен ортасына танымалы, бірақ қалың оқырман қауым үшін мағынасы бейтаныс сөздер мен ұғымдар маңына тіреледі. Бұл аталған термин сөздердің көбі Абайдың қарасөздерінде мол қолданылса да, олардың мағыналық төркіні өлеңдерінде де жатады» (Мырзахметұлы,
2020: 70) деген тұжырымы Абай ілімінің ақын шығармашылығын түгел қамтитынын негіздейді.

«Абай ілімі» тұтас, бірбүтін дүние. «Абайдың антропологизмі» дегенде, ойымызда «Абайдың адам туралы ілімі» деген ұғым тұрады. Дұрысы - Абайдың ілімі... Абайдың ілімін «әділет туралы», «адамгершілік туралы» немесе «толық адам туралы» деп атаудан тартынамыз. Біздің байқауымызша, Абайдың ілімі туралы осы атаулардың бәрі де негізсіз емес» (Дәдебаев, 2016: 3). Қазіргі абайтануда зерттеулерге негіз болған Абайдың шығармашылығындағы ілімдерді «әділет туралы», «адамгершілік туралы» немесе «толық адам туралы» деп атау белгілі бір деңгейде дұрыс пайым. Сонымен қатар Абай ілімінің біртұтас жүйесін жасау, оны білу, түсіну және қолдану толыққанды зерттеуді қажет ететінін зерттеу маңызды.

\section{Нәтижелер мен талқылау}

Абай жетінші қара сөзінде жас бала анадан туғанда екі түрлі мінезбен туады дейді. Біреуі ішсем, жесем, ұйықтасам деп тұрса, біреуі білсем екен, көрсем екен дейді. Алғашқысын тән құмарлығына жатқызса, екіншісін жан құмарлығына жатқызады. Тән нәпсісін тыя алмасақ, хайуанның жанынан адамның жанының несі артық. Дүниенің көрінген һәм көрінбеген сырын түгелдеп, ең болмаса денелеп білмесе, адамдықпен орны болмайды. Оны білмеген соң, ол жан адам жаны болмай, хайуан жаны болады. Абайдың қағидасы бойынша, адамның адамдығы дүниенің көрінген һәм көрінбеген сырын түгелдеп, ең болмаса денелеп білуінде. Оны білмеген адамды хайуанға қосуға болады. Демек, Абай шығармашылығындағы білім концептісі адам баласы үшін өмірлік маңызы бар қасиеттердің, ол қасиеттерді білдіретін ұғымдардың негізі болып табылады.

Абайдың білу, білім туралы ойы терең. Біздің талдауларымыз, байқауларымыз бойынша, Абай осы сөзінде білім алудың екі түрлі жолын көрсеткен: 1) дүниенің көрінген һәм көрінбеген сырын түгелдеп білу; 2) дүниенің көрінген сырын денелеп білу. Мұның біріншісі - оқу, үйрену арқылы алынатын (келетін) дүниенің қандай да бір қыр-сыры туралы түсінік (таным) деңгейіндегі білім; Екіншісі - Абайдың өзі сипаттаған жол (денелеп білу) арқылы алынатын білім.

Абайдың жетінші қарасөзін талдау барысында «Білім» концептісі тоғыз мәрте эксплицитті 
түрде, бір рет имплицитті түрде қолданылатыны белгілі болады. Ал «Сенім» концептісіне келер болсақ, эксплицитті түрде бір рет қана вербалданған.

Біздіңше «білім», «сенім» сөздеріне берілген түсініктердің әрқайсысы қосымша түсінікті талап етеді. Бұл, әрине, «Абай тілі сөздігіне» қатысты айтылған сын емес, «білім», «сенім» сөздерін концептуалдық деңгейде қарастыруға қажетті базалық мәліметтердің жүйесінде олқылық бары туралы ойымыздың бір ұштығы деуге лайықты.

Абай шығармашылығындағы «білім» және «сенім» концептілері лингвомәдени концептілердің тобына жатады. Олардың құрылымын, топтарын, моделін анықтау қажеттігі дау тудырмайды. Екінші жағынан бұл концептілер құндылықтар туралы ұғымдар, қағидалар жүйесімен сабақтасып жатыр. Сол себепті «білім» де, «сенім» де Абай ілімінің концептуалды моделін түзетін құндылықтар категориясымен байланысты.

Білім және сенім концептілері Абай шығармашылығында белгілі бір тілдік немесе семантикалық бірлік қана емес. Олар - ақын ілімінің арнасында өз алдына жеке категория деңгейінде сараланған этномәдени құбылыстар. Сондықтан білім және сенім концептілері Абай шығармашылығында әлеуметтік өмірдегі рухани құндылықтар туралы таным моделінің концептуалдық сипаттамасын білдіреді.

Абайдың тірлік, өмір туралы ойларының жүйесінде құнды қағидалар қатары бар. Солардың бірінде ақын былай дейді: «Дүниенің көрінген һәм көрінбеген сырын түгелдеп, ең болмаса денелеп білмесе, адамдықтың орны болмайды. Оны білмеген соң, ол адам жаны болмай, хайуан жаны болады» (Абай, 2016b: 96). Осы қағиданың жоғарыда көрсетілмеген қырына назар аударайық. Қағида силлогизм түрінде негізделген. Оның құрамдас бөліктерін мынадай мағыналық бірліктерге даралауға болады: а) дүниенің көрінген һәм көрінбеген сырын түгелдеп, ең болмаса денелеп білу; ә) адамдықтың орны. Кейінгі бірлік (ә) деңгейіндегі мәннің болуының шарты - алдыңғы бірлік (a) деңгейіндегі мәннің болуы. Алдыңғы бірлік (a) деңгейіндегі мән болмаған жағдайда (дүниенің көрінген hәм көрінбеген сырын түгелдеп, ең болмаса денелеп білу) кейінгі бірлік (ә) деңгейіндегі мән (адамдық) ашылмайды. Осы бірліктер деңгейіндегі қағиданы қарапайым құрылымға түсіргенде, адамдықтың негізі білімде екенін өрнекке түсіруге болады.
Абай шығармашылығында негізделген ойлар мен қағидалардың оның ілімі жүйесінде белгілі бір орны бар. Олардың орнын, мәнін, мағынасын, жүйедегі қызметін білу маңызды. Алайда олардың бәрін ақын ілімінің мағыналыққұрылымдық жүйесіне енгізу міндетті емес. Ақын ілімінің концептуалды моделі оның ілімінің басты құрамдастары негізінде жасалды. Абай ілімі мағыналық-құрылымдық моделін жасау барысында мына жайлар анықталды: ақынның ілімі біреу емес, екеу. Оның бірі адам туралы, екіншісі әр жақсы нәрсенің өлшемі туралы. Бұлардың әрқайсысының моделі бөлек және екі үлгіде жасалды:

Абай ілімінің құрамдас бір бөлігі - әр жақсы нәрсенің өлшемін көрсететін өлшеу құралы. Абайдың қырық үшінші сөзіндегі: «Әрбір жақсы нәрсенің өлшеуі бар, өлшеуінен асса, жарамайды. Өлшеуін білмек - бір үлкен керек іс» (Абай, 2016b: 152), - деген тұжырымды ойда үлкен мән бар. Абай айтқан әрбір жақсы нәрсенің өлшеуі үштаған, төрттаған үлгісінде жобаланады, бұлардың әрқайсысы еселеніп, басқа өлшем құралына негіз болады.

Үш мөлшерлі өлшем құралы туралы ойдың негізі ерте замандардан бері жалғасып келеді. Оның Платон мен Аристотельден әл-Фарабиге, одан Абайға дейін жалғасқан желісі бар. Осы желіні тану Абайдың ілімінің тереңіне бойлаудың қаншалықты маңызды екенін көрсетеді. Осы концептуалды ой желісінің басында ең әділетті нәрсе әділеттілік пен әділетсіздіктің ортасы деген тұжырым бары ілгеріде айтылды. Оны негіздеген - Платон. Осы тектес ойды Аристотель, әлФараби, Абай өз тұрғысынан айтқан. Олардың әрқайсысы өз мақсаттарына сай пікір түйді. Әл-Фарабидің қалыптасқан мінез-құлықтың үш деңгейін көрсетті: не орташаға жақын халде; не орташа халде; орташадан асыңқы халде. Абай осы тектес ойлардың түпкі негізіне бойлады. Құбылыстың, нәрсенің үш деңгейі туралы ойлардың түп негізіне бойлап қана қоймай, оларды өз пікірлерімен ұштастырды, дамытты, әрбір жақсы іс пен оның қарама-қарсы шегіндегі істердің өлшеуінің логикалық негізін тиянақтады, логикалық-мағыналық үлгі-моделін жасады. Абайдың өлшеу құралының моделі нәрсенің, құбылыстың үш түрлі халіне сай үш деңгейді көрсетеді: а) басы (ортаға жақын шамасы); ә) ортасы (орта шамасы); б) аяғы (ортадан асыңқы шамасы). Мұндағы бірінші және үшінші деңгейлер нәрсенің, құбылыстың қарама-қарсы мәндегі шеткергі екі шегіндегі қасиеттерін көрсетеді, ал қарама-қарсы мәндегі 
шеткергі екі шектің орта шамасы нәрсенің немесе құбылыстың жақсы, кемел деуге лайықты деңгейін көрсетеді. Осы үштағанды Абай өз іліміндегі әр жақсы нәрсенің өлшеуіне негіз етіп алған.

Әрбір жақсы нәрсенің өлшеуі туралы Абай ілімінің құрылымдық жүйесінің логикалықмағыналық үлгі-моделі екі үлгіде жобаланды: а) кескіндеме түрінде; ә) өрнек түрінде.

Бірінші үлгі мынадай түрде кескінделді: өлшемге түсетін белгілі бір қасиет шеңбер аясы түрінде бейнеленеді.

Өлшемге түсетін қасиетті өлшеудің құралы сол шеңбердің ішінде беріледі; шеңбер ішінде берілген өлшеу құралы қазақ халқының дәстүрлі дүние танымына сәйкес шаңырақ түрінде беріледі. Шеңбердің ортасынан А - В көлбеу сызығы жүргізіледі, шеңбердің жоғарғы шекті нүктесінен төменгі шекті нүктесіне С - Д сызығы жүргізіледі. Халықтың дәстүрлі дүние танымында «төрткүл дүние» немесе «төрт құбыла» («төрт құбыласы түгел», «дүниенің төрт бұрышы» ұғымына сәйкес) осы символбелгі арқылы өрнектелген.

Енді А - C, С - В нүктелері бойынша тік сызықтар жүргіземіз.

Осы кескіндемедегі А - C - В үшкілі - әрбір жақсы нәрсенің өлшеу құралы.

Осы өлшеу үлгісіне салғанда, әр жақсы нәрсе орта шамада (C) жақсы болады да, оған жетпесе немесе одан асып кетсе, өз мәнін жояды немесе жартылай жояды. Абай насихат еткен бес жақсы істің әрқайсысын (талап, еңбек, терең ой, қанағат, рақым) (Абай, 2016а: 60) осы өлшеу үлгісіне салып, таразылауға болады. Мысалы, ойлау жақсы, бірақ оның орта шамасын (C) білу керек. Ой ойлаймын деп, орта шамаға (C) жете алмау немесе одан асып кету, сөйтіп ойын байлай алмай, күні-түні ойға салынып, қияли болып кеткен жақсы емес. Сол сияқты жомарт болған жақсы, ал оның өлшеуінің орта шамасына «С» жете алмау - сараңдыққа, ал одан асып кету ысырапшылыққа, бекер мал шашуға әкеліп соғады.

Осы өлшеу үлгісіне салғанда, әр жақсы нәрсе орта шамада жақсы болады да, орта шамадан асқан соң, өз мәнін жоғалтып, қарама-қарсы мәндегі құбылысқа айналады. Абай насихат еткен бес жақсы істің әрқайсысын (талап, еңбек, терең ой, қанағат, рақым) осы өлшеу үлгісіне салып, таразылауға болады. Мысалы, ойлау жақсы, бірақ оның орта шамасын білу керек. Сол сияқты жомарт болған жақсы, ал оның өлшеуінің орта шамасына жете алмау немесе одан асып кету жақсы емес.
Абай шығармашылық мұрасына арқау еткен ұлттық және жалпыадамзаттық құндылықтарды осы өлшемдер негізінде саралап, жүйелеген.

Абайдың шығармашылығында жаман деген істің өзі үш өлшемді өлшеу құралында сарапталады. Мысалы, ақын адамның бес дұшпаны деп білген бес жаман істің бірі мақтаншақ туралы желілі ойларын тарата келіп, мақтаншақ адамдарды үшке бөледі: «Біреуі жатқа мақтанарлық мақтанды іздейді... Екіншісі өз елінің ішінде мақтанарлық мақтанды іздейді... Үшіншісі өз үйіне келіп айтпаса, яки аулына ғана келіп айтпаса, өзге кісі қостамайтын мақтанды іздейді» (Абай, 2016b: 107). Бұлардың біріншісі - надан, надан да болса адам; екіншісінің надандығы толық, адамдығы толық емес; үшіншісі - наданның наданы ләкин өзі адам емес.

Ақын іліміндегі қарама-қарсы мағыналық қатынастағы адам мен надан категорияларынан наданды бөліп алып, оны Абайдың үш деңгейлі өлшем құралына салғанда, наданның мынадай үш деңгейлі халі белгілі болады: а) надан, надан да болса адам; ә) надандығы толық, адамдығы толық емес; б) наданның наданы ләкин өзі адам емес.

Надан, надандық өлшемінің деңгейлерін өзара сабақтас пайымдағанда, ақын ойының тереңінен көзге шалынып, көңілге елесі жеткен образды ұғымдар нақтыланады. Абай көрсетіп отырған үш деңгейдің алғашқысы бейнелі, кейінгі екі деңгей затты, нақты екені сипатталады. Абай өлшемінде затты, нақты көрсетілген кейінгі екі ұғым қатарынан бірінші деңгейде көрініс тапқан образды ұғымды даралағанда, «надан, надан да болса адам» көрсеткішінен кісі бойындағы надандаңдық пен адамдықтың бірдей шамадағы мөлшері туралы ұғым туатыны көрсетіледі. Екінші шамада надандық толық сипатта көрінетіні, ал адамдықтың толық емес, кем екені, үшінші шамада кісі бойында надандық шектен асып кететіні, адамдыққа орын қалмайтыны белгілі болатыны сарапталады.

Пайымдалған жайлардан Абайдың өлшеу құралы жақсыны да, жаманды да мөлшерлейтін әмбебап құрал екені туралы түсінік туады.

Абайдың ілімі бойынша, дүние әділеттілікпен жаратылған. Әділеттілік - махаббаттан, махаббат - жүректен. «Махаббат - әуел адамның адамдығы, ғақыл, ғылым деген нәрселербірлән» (Абай, 2016b: 124). Даналыққа білім жеткізеді. Осы құндылықтарды себеп-салдарлық қатынаста ретке келтіретін болсақ, мынадай жүйе түзіледі: білім $\rightarrow$ даналық $\rightarrow$ әділеттілік. Осы жерде «әділеттілік $\rightarrow$ махаббаттан» немесе «қашан бір 
бала ғылым, білімді махаббатпенен көксерлік болса, сонда ғана оның аты адам болады» (Абай, 2016b: 124) деген қағида назардан тыс қалғандай болуы мүмкін. Махаббатсыз әділеттілік болмайды. Махаббатсыз білім де болмайды. Махаббат осы жүйеде көрсетілген білім, ғылым, даналық, әділеттілік төртеуіне бірдей негіз болмақ.

Абай ілімінің құрылым-жүйесінде әділеттің, әділеттіліктің салтанат құруына даналық негіз болатыны, даналыққа білім негіз болатыны туралы ойлардың қалың қатары қарастырылды. Білім жоқ жерде даналыққа орын жоқ, даналақ жоқ жерде әділеттілік болмайды. Білімнің жоқтығы - надандақ, ал надандық хайуандықпен пара-пар.

Айтылған, сипатталған жайлардан Абайдың шығармашылық мұрасының өрісінде, Абайдың ілімінің жүйесінде білім туралы қағидалардың маңызы зор екені белгілі болады.

Мақалада Абай ілімінің құрамдас бөлімдерінің құрылым-жүйесіндегі жекелеген бөліктердің үлгі-моделін жобалайтын формулалар үлгісі жасалды: а) адам болмысының формуласы; ә) хайуан болмысының формуласы; б) кемел адам болмысының формуласы; в) надан адам болмысының формуласы, т.б.

Сипатталып отырған үлгі-модельдер ғылыми талдаулар шегіндегі жекелеген, жалқы құбылыстардың құрылымдық-мағыналық сұлбасы (жобасы) деңгейінде жасалады. Олардың күрделі болмыс жүйесіндегі толымды нұсқасын жасау біртіндеп жүзеге асырылды.

Талдаулар негізінде жаңа ғылыми ойлар, тұжырымдар ұсынылды, сарапталды. Абай ілімінің концептуалды моделінің қысқаша сипаттамасы төмендегідей үлгіде берілді:

1 Абай ілімінің қысқаша сипаттамасы

Абай ілімі Абайдың шығармашылық мұрасының ұлттық және жалпыадамзаттық құндылықтарының жүйесінің концептуалдық моделі түрінде ұсынылды. Абай ілімінің концептуалдық моделі ықшамдалған үлгіде беріліп отыр.

2 Абай ілімінің құрамдас бөлімдері

Абай ілімінің құрамдас бөлімдері ақынның шығармашылық мұрасында кең көрініс тапқан адамның үш қасиеті туралы қағидалар жүйесіне негізделген: Ақыл. Қайрат. Жүрек.

\section{1 Ақыл}

\subsection{1 Сипаттары}

Ақылдың тоқтаулылығы; ақылдың ар мен ұятқа беріктігі; ақылсыз пайданы іздеуге болмайды (пайдаға ақыл жеткізеді); ақылсыз залалдан қашып құтылу мүмкін емес (залалдан ақыл құтқарады); ақылсыз ғылымды ұғып, үйрену жоқ (ғылымды ақыл ұқтырып, ақыл үйретеді); ақылсыз ешнәрсе табылмайды (керектің бәрін ақыл табады); ненің пайдалы, ненің залалды екенін ақыл біледі; ақыл сөзді ұғады; тәңіріні де ақыл танытады; екі дүниенің жайын да ақыл біледі; амал да, айла да ақылдан шығады; ақылдың қыры көп; ақыл - жүректің суаты; ақылға сәуле қонады; ақыл қайраттан асып тұрады т.б.

\section{2 Қайрат}

\subsection{1 Сипаттары}

Дүниеде ешнәрсе қайратсыз кәмелетке жетпейді; адамның білуге ерінбей, жалықпай үйренуі-қайраттың ісі; құдайға лайықты ғибадат қылып, ерінбей, жалықпай орнына келтірмек қайраттың ісі; дүниеге лайықты өнер, мал тауып, абұйыр, мансапты еңбекпен табу - қайраттың ісі; орынсыз, болымсыз нәрсеге үйір қылмай, бойды таза сақтайтұғын, күнәкәрліктен, көрсеқызар жеңілдіктен, нәфсі шайтанның азғыруынан құтқаратұғын - қайрат; адасқан жолға бара жатқан бойды қайта жиғызып алатұғын - қайрат; қаруына қарай қаттылығы да бар; пайдасы да, залалы да мол; кейде жақсылықты берік ұстайды, кейде жамандықты берік ұстайды; тоқтаулылық; талаптылық; шыдамдылық т.б.

2.3 Жүрек

\subsection{1 Сипаттары}

Жүрек - адамның денесінің патшасы; қан жүректен тарайды; жан жүректе тұрады; жүрексіз тіршілік жоқ; адамға жақсылық ойлататын, басқаларға жанын ашытатын - жүрек; ұят сақтатып, рақым қылдыратын - жүрек; адам баласын алаламайды; ждақсылыққа елжіреп, ериді; жаманшылыққа жиреніп, тулап кетеді; әділет, нысап, ұят, рақым, мейірбаншылық жүректен шығады; ақылдың көп қырына жүрмейді, жаманшылық айтқанына ермейді, қайратты еркіне жібермейді, орынды іске қолын босатпайды, орынды іске күшін аятпайды т.б.

Абай ілімінің құрамдас бөлімдерінің тиісті категориялары бар. Бұл ретте ақыл, қайрат, жүрек үшеуінің бірлескен тең қызметі арқылы анықталатын негізгі категориялар қатарында адамның бес жақсы ісі (талап, еңбек, терең ой, қанағат, рақым) мен бес дұшпаны (өтірік, өсек, мақтаншақ, еріншек, бекер мал шашпақ) ерекше орын алады.

\section{Қорытынды, тұжырымдар}

Ғылымда Абайдың ілімі туралы, оның сипаттары туралы бірқатар ғылыми ойлар жинақталған. Олардың маңызы жоғары. Зерттеу 
барысында бұл саладағы ғылыми ойлар толық пайымдалды. Сонымен қатар Абайдың ілімі жайында жинақталған ғылыми ойлар қоры болғанмен, Абай ілімінің жүйесі, құрамдас бөлімдері, олардың тарамдары ғылыми тұрғыда таратылып көрсетілмегені ескерілді. Абай ілімінің логикалық-мағыналық жүйесінің концептуалды моделін жасаудың бірінші кезегінде көп бағытты ғылыми талдаулар, саралаулар мен сараптаулар жүргізілді.

Абай ілімін білу, түсіну және қолдану мақсатында жүргізілген ізденіс жұмыстары нәтижесінде Абайдың ілімі, оның құрамдас бөлімдері туралы жаңа ғылыми пікірлер дәйектелді. Абай ілімінің құрамдас үш бөлімі туралы ойлар дамытылды, жүйеленді. Абай ілімінің үш құрамдас бөлімінің әрқайсысы бойынша кеңейтілген ғылыми талдау жұмыстары жүргізілді. Абай ілімінің құрамдас бөлімдерінің ғылыми сипаттамасы жаңа ойлармен толықтырылды, олардың әрқайсысының бағыт-бағдары, тегеуріні, өлшеуі туралы ойлар негізделді, олардың өзара байланыстары екшелді, сабақтас және қарама-қайшы мағынадағы шектері жүйесіндегі мәні сарапталды. Абайдың ілімінің құрамдас бөлімдерін осылай анықтау мен жүйелеу маңызды нәтижелерге қол жеткізді.
Абай шығармашылығында негізделген ойлар мен қағидалардың оның ілімі жүйесінде белгілі бір орны бар. Олардың бәрінің орнын, мәнін, мағынасын, жүйедегі қызметін білу маңызды. Алайда олардың бәрін ақын ілімінің мағыналыққұрылымдық моделіне енгізу міндетті емес. Ақын ілімін білу, түсіну және қолдану оның ілімінің басты құрамдастары негізінде жасалды. Абай ілімі мағыналық-құрылымдық моделін жасау барысында мына жайлар анықталды: ақынның ілімі біреу емес, екеу. Оның бірі адам туралы, екіншісі әр жақсы нәрсенің өлшемі туралы. Жоба орындаушылары Абайдың ілімінің біреу емес, екеу екені туралы пікірді ғылыми тұрғыда негіздеді. Екі ілімнің болмысы, құрылым жүйесі екі бөлек екені сараланды. Бірақ олардың жалпы сипаттамасын бір ілім шеңберінде беруді дұрыс көрді.

Зерттеу нәтижелерінің ғылыми және практикалық маңызы бар. Абай ілімінің логикалықмағыналық үлгі-модельдерін абайтану ғылымы мен абайтануды оқыту ісінде бірдей пайдалануға болады.

Мақала АР08855683 «Абай ілімін білудің, түсінудің және қолданудың ғылыми негіздері мен теориялық тетіктері» ғылыми жобасы аясында жазылды.

\section{Әдебиеттер}

Мырзахметов М. Мұхтар Әуезов және абайтану проблемалары. Кітапта: Абайтану. Таңдамалы еңбектер. XXI том. / баспаға дайындағандар: Б. Баязитов, П. Бисенбаев, Г. Ысқақова; жалпы ред. басқ. Ж. Дәдебаев. - Алматы: Қазақ университеті, 2017. - 290 б.

Әуезов М. Абай (Ибраһим) Құнанбайұлы. Монография // Әуезов М. Жиырма томдық шығармалар жинағы. - Т. XX. Алматы: Жазушы, 1985. - 6-245 б.

McGuire G. The Image of Abai in Kazakh Novels: The Case of Auezov - 2020. / URL: https://abaicenter.com/the-image-ofabai-in-kazakh-novels

Tarakov, A.S., Azimbayeva, I.K., Abdullayeva, Z.T. Translation problems of phraseological units: On the basis of M. Auezov's Novel the Way of Abai. Mediterranean Journal of Social Sciences, 2015, 6(4S2), cтр. 370-374

Zhaparova, A. Translating the Kazakh poet Abay. Journal of Language and Literature, 2016, 7(4), стр. 307-314

Daurenbekova L.N., Imanberdiyeva S.K. and others. Translation and interpretation of Abay's political and social lyrics into Turkic languages. Opción, v. 36, p. 1849-1868, 24 apr. 2020.

Kudaibergenova D. Who is Abai for contemporary Kazakhstan? - 2020. / URL: https://abaicenter.com/who-is-abai-for-contemporary-kazakhstan

Auezov M. The Modernist Way of Abai - 2020. / URL: https://abaicenter.com/the-modernist-way-of-abai

Baizakova K. The great thinkers of Al-Farabi and Abai: a comprehension of their heritage - 2020. / URL: https://abaicenter. com/great-thinkers-al-farabi-abai

Zhaparova, A.Z. The functional characteristics of a metaphor in Abay's poems. Journal of Language and Literature, 2016, 7(1), стр. 42-52

Zhaparova, A.Z., Dadebaev, Z., Zhaksylykov, A. The conceptual metaphor in Abay Kunanbayev's poetics. Journal of Language and Literature this link is disabled, 2016, 7(3), стр. 54-59.

Мырзахметұлы М. Абай: Толық адам ілімі. / Абайтану. Таңдамалы еңбектер. XL том: - Алматы: Қазақ университеті, 2020. - 238 б.

Дәдебаев Ж. Абайдың антропологизмі / Абайтану. Таңдамалы еңбектер. Х том.. - Алматы: Қазақ университеті, 2016. -269 б. 
Абай (Ибраһим) Құнанбайұлы. Шығармаларының екі томдық толық жинағы. I том. - Алматы: Жазушы, 2016. - 296 б. Абай (Ибраһим) Құнанбайұлы. Шығармаларының екі томдық толық жинағы. II том. - Алматы: Жазушы, 2016. - 336 б.

\section{References}

Abai (Ibrahim) Qunanbaiuly. (2016a). Shygarmalarynyng eki tomdyq tolyq zhinagy. I tom. [Complete collection of works in two volumes. Vol I] Almaty: Zhazushy. (in Kazakh)

Abai (Ibrahim) Qunanbaiuly. (2016b). Shygarmalarynyng eki tomdyq tolyq zhinagy. II tom. [Complete collection of works in two volumes. Vol II] Almaty: Zhazushy. (in Kazakh)

Auezov M. (1985). Abai (Ibrahim) Qunanbaiuly. Monografia [Abai (Ibrahim) Qunanbaiuly. Monograph] Almaty: Zhazushy. (in Kazakh)

Auezov M. (2020), The Modernist Way of Abai / URL: https://abaicenter.com/the-modernist-way-of-abai

Baizakova K. (2020), The great thinkers of Al-Farabi and Abai: a comprehension of their heritage / URL: https://abaicenter. com/great-thinkers-al-farabi-abai

Dadebaev Zh. (2016). Abaidyng antropologizmi [Abai's anthropology] Almaty: Qazaq universiteti. (in Kazakh)

Daurenbekova L.N., Imanberdiyeva S.K. and others. Translation and interpretation of Abay's political and social lyrics into Turkic languages. Opción, v. 36, p. 1849-1868, 24 apr. 2020.

Kudaibergenova D. (2020), Who is Abai for contemporary Kazakhstan? / URL: https://abaicenter.com/who-is-abai-for-contemporary-kazakhstan

McGuire G. (2020). The Image of Abai in Kazakh Novels: The Case of Auezov / URL: https://abaicenter.com/the-image-ofabai-in-kazakh-novels

Myrzahmetov M. (2017). Mukhtar Auezov zhane abajtanu problemalary. [Mukhtar Auezov and problems of Abai studies] Almaty: Qazaq universiteti. (in Kazakh)

Myrzahmetuly M. (2020). Abai: Tolyq adam ilimi. [Abai: The doctrine of the whole man] Almaty: Qazaq universiteti. (in Kazakh)

Tarakov, A.S., Azimbayeva, I.K., Abdullayeva, Z.T. (2015). Translation problems of phraseological units: On the basis of M. Auezov's Novel the Way of Abai. Mediterranean Journal of Social Sciences, 6 (4S2).

Zhaparova, A. (2016). Translating the Kazakh poet Abay. Journal of Language and Literature, 7 (4)

Zhaparova, A.Z. (2016a). The functional characteristics of a metaphor in Abay's poems. Journal of Language and Literature, 2016, 7(1), str. 42-52

Zhaparova, A.Z., Dadebaev, Z., Zhaksylykov, A. (2016b). The conceptual metaphor in Abay Kunanbayev's poetics. Journal of Language and Literature this link is disabled, 7(3). 